\title{
Nutritional valorisation of cane (Arundo donax) by treatment with sodium hydroxide
}

\author{
S.M.P. Teixeira", C.S.A.M. Maduro Dias, C.F.M. Vouzela, \\ J.S. Madruga \& A.E.S. Borba
}

University of the Azores, FCAA, Institute of Agricultural and Environmental Research and Technology, Rua Capitão João d’Ávila, 9700-042 Angra do Heroísmo, Açores, Portugal.

(Received 14 January 2021; Accepted 15 March 2021; Published 10 July 2021)

\author{
Copyright resides with the authors in terms of the Creative Commons Attribution 4.0 South African Licence. \\ See: http://creativecommons.org/licenses/by/4.0/za \\ Condition of use: The user may copy, distribute, transmit and adapt the work, but must recognise the authors and the South African \\ Journal of Animal Science.
}

\begin{abstract}
This study evaluated the effects of sodium hydroxide $(\mathrm{NaOH})$ treatment on the nutritional value of Arundo donax (A. donax). Its ultimate goal was to develop an environmentally friendly animal feed alternative that could be produced sustainably while combatting the spread of $A$. donax. Plants were collected and dried at $60{ }^{\circ} \mathrm{C}$ in an oven with controlled air circulation to determine the dry matter (DM) content. The dry plant material was then sprinkled with an $\mathrm{NaOH}$ solution of $2 \%, 4 \%, 6 \%$, or $8 \%$ and placed in leak-proof containers for four weeks. The chemical and in vitro digestibility properties of treated and untreated $A$. donax samples were analysed in triplicate. The treatment led to significant decreases in neutral detergent fibre (NDF) from $81.06 \%$ DM to $69.39 \%$ DM, acid detergent fibre (ADF) from $46.99 \%$ DM to $43.19 \%$ DM, and ether extract (EE) from $2.06 \% \mathrm{DM}$ to $1.39 \% \mathrm{DM}$, in the untreated samples compared with those treated with $8 \% \mathrm{NaOH}$, respectively. In addition, DM digestibility increased from $24.61 \%$ to $33.78 \%$, ash content from $11.75 \% \mathrm{DM}$ to $19.92 \% \mathrm{DM}$, and $\mathrm{ADL}$ from $7.43 \% \mathrm{M}$ to $15.38 \% \mathrm{DM}$. Thus, treatment of $A$. donax with an $8 \%$ solution of $\mathrm{NaOH}$ concentration improved its nutritional value.
\end{abstract}

Keywords: digestion kinetics, gas production, in vitro digestibility

\#Corresponding author: sofia.mp.teixeira@uac.pt

\section{Introduction}

Minimizing concentrate feeds and maximizing the use of forages have become increasingly important considerations for the diets of ruminant animals. However, the low digestibility of forages relative to concentrates can compromise animal production.

The feeding of ruminants in the Azores is based mainly on grass, specifically Graminaceae. Each year the production of grass is insufficient to meet the nutritional requirements of the animals in the dry months. Thus, the dry season causes nutritional stress and decreases animal productivity. A forage deficiency makes it necessary to import feedstuffs (Borba, 2015). However, supplementation with concentrates during the dry season may not be a profitable practice owing to high costs. A potential strategy to increase the quality and availability of food for ruminants in the dry season may be through feeding unconventional bushes and forages (Pezo, 1991) such as Pittosporum undulatum, Hedychium gardnerianum, Morella faya and Ilex perado (Borba, 2007). Shrubs and non-conventional forages are low-quality fibrous products that are characterized by cellulose, hemicellulose, and lignin contents of around $70 \%$, and low concentrations of soluble carbohydrates, protein, minerals, and vitamins. Such products do little to stimulate the cellulolytic flora of the reticulum-rumen, making their fibrous structure inadequately degradable. Given that these foods have low food value, low digestibility, and low voluntary intake, they do not satisfy the maintenance needs of ruminants (Borba, 2006; Rocha, 2016).

Physical, chemical and biological treatment of low-quality roughages could provide quality fodder, meeting the nutritional requirements of the animals and mitigating the effects of the scarcity of high-quality forage (Bertipaglia et al., 2005). In recent years, several studies have been carried out on the valorization of Hedychium gardnerianum (Borba et al., 2015). However, treatment of green Hedychium gardnerianum fodder with urea did not have the same effect as similar treatment of low-quality fibrous straws, because the green fodder had a much higher crude protein content than the straws. Rocha et al. (2019) studied A. donax 
treated with urea and concluded that treatment with urea at $3.5 \%$ of DM had no significant effect on its nutritional value and postulated that other treatments might be more effective.

Arundo donax, commonly known as giant cane or elephant grass, is a robust perennial herb that can be found from coastal dunes, cliffs, and coastal wetlands to bushes, permanent and semi-natural pasture, as well as in agricultural areas and anthropic vegetation. It is one of most widespread Macaronesian invasive plants. Arundo donax infestations create serious physical and biological problems. Its biomass creates obstacles during storm events, and can lead to flooding of adjacent lands, erosion of stream banks, and change in natural flow patterns. Therefore, it was proposed to study the effect of treatment of $A$. donax with $\mathrm{NaOH}$ on the chemical composition and nutritional value of the residue to see if it could be used by Azorean farmers to feed livestock. If such treatment were found to make a useful feedstuff, then the vegetative propagation of $A$. donax might be reduced.

\section{Material and Methods}

The present study was conducted in Prof. Doutor Gourlay Young do Amaral Animal Nutrition Laboratory, Department of Agricultural Sciences, University of the Azores, Angra do Heroísmo, Terceira, Azores, Portugal. The plant, which was harvested manually in full vegetative state in Terceira Island was chopped to pieces that were approximately $10 \mathrm{~cm}$ long. The samples were sprayed with $\mathrm{NaOH}$ solution (control group, $2 \%, 4 \%, 6 \%$, and $8 \%$ ). For each treatment, $1 \mathrm{~kg}$ samples were placed in plastic boxes with lids and observed for seven days. After treatment, the samples were dried in a forced air oven at $65{ }^{\circ} \mathrm{C}$ for 72 hours.

Dried samples were then ground through a 1-mm screen using a Retsch mill (GmbH, 5657 Haan, Germany). These ground samples were analysed for DM (method 930.15), crude protein (CP) (method 954.01) and total ash (method (42.05), according to AOAC (1995). Briefly, the dry matter content was determined by placing samples in a forced air oven at $105^{\circ} \mathrm{C}$ for 24 hours. Ash was measured by burning samples in a muffle furnace at $500{ }^{\circ} \mathrm{C}$ for 12 hours. Crude protein was determined by the standard microKjeldahl method, using digestion equipment (Kjeldatherm System KT 40, Gerhart Laboratory Instruments, Bonn, Germany) and an automated Kjeltec 2300 auto-analyser apparatus for distillation and titration (Foss Electric, Copenhagen, Denmark). Acid detergent fibre (ADF), acid detergent lignin (ADL) and neutral detergent fibre (NDF) were determined following the methods of Goering and Van Soest (1970). In vitro digestibility was determined using the Tilley and Terry (1963) method as modified by Alexander \& McGowan (1966). The rumen fluid used in assaying in vitro digestibility was obtained from a local slaughterhouse.

Each assay was repeated three times using the in vitro gas production (GP) technique which simulates rumen fermentation. This technique is used to evaluate the potential for ruminant animals to produce greenhouse gases when fed a particular feedstuff. Blanks were used for each inoculum to measure the fraction of total gas production because of substrate in the inocula and these values were subtracted from the total to obtain net GP. All treatments were incubated simultaneously (Menke et al., 1979). The preparation of buffer solutions and rumen inocula was as described by Menke and Steingass (1988). Gas production was recorded after 4, 8, 12, 24, 48, 72, and 96 hours of incubation. Kinetics of the in vitro gas production were described using an exponential model (McDonald, 1981; Ørskov \& McDonald, 1979):

$$
p=a+b\left(1-\exp ^{-c t}\right)
$$

where: $p$ was the gas production at time $t$;

the values of $a$ and $b$ were constant values in the exponential equation with their sum predicting total potential gas production $(\mathrm{ml} / \mathrm{g} \mathrm{DM})$, and

$c$ was the rate constant.

The parameters were estimated using the Neway software program (Rowett Research Institute, Aberdeen, UK), which was developed by Chen (1997).

Effects of the treatments on the parameter estimates were assessed using SPSS (IBM SPSS Statistics for Windows, version 24.0., IMB Corp., Armonk, New York, USA). Normality of the data was evaluated with the Shapiro-Wilk test and ANOVA was performed, followed with post-hoc Tukey least significant difference test. For all analyses, a $P$-value less than 0.05 was considered to indicate a difference.

\section{Results and Discussion}

Owing to its high fibre and low protein contents, A. donax foliage is digested poorly. In a study by Rocha et al. (2019) urea was applied to A. donax, but the concentration that was used did not produce favourable results. That motivated the use of $\mathrm{NaOH}$ in the current study. Also, Pires et al. (2006) concluded that $\mathrm{NaOH}$ and calcium hydroxide were more efficient than urea in degrading the cell wall and increasing 
digestibility. In the current study, chemical treatment of $A$. donax with sodium hydroxide $(\mathrm{NaOH})$ affected some of its nutritional components (Table 1). There was a difference in DM between treatments with $2 \%$ and $8 \% \mathrm{NaOH}$. Treatment with $2 \% \mathrm{NaOH}$ decreased $(P<0.05)$ the amount of $\mathrm{CP}$ relative to both the untreated control and the $4 \% \mathrm{NaOH}$ treatment. However, treatment of the forage with higher levels of $\mathrm{NaOH}$ did not alter the CP content significantly. The changes in NDF and ADF were similar across treatments, with the fibre contents being reduced as the level of $\mathrm{NaOH}$ applied was increased. Treatment with $8 \% \mathrm{NaOH}$ reduced the EE content relative to the other treatments, which performed similarly. The ash content increased with increased levels of $\mathrm{NaOH}$. However, these effects did not manifest themselves in changes of dry matter digestibility (DMD).

Table 1 Chemical composition and nutritive value of Arundo donax when augmented with various levels of sodium hydroxide

\begin{tabular}{lccccc}
\hline \multirow{2}{*}{ Nutrient } & \multicolumn{5}{c}{ Treatment } \\
\cline { 2 - 6 } & Control & $2 \% \mathrm{NaOH}$ & $4 \% \mathrm{NaOH}$ & $6 \% \mathrm{NaOH}$ & $8 \% \mathrm{NaOH}$ \\
\hline $\mathrm{DM}, \%$ & $33.66^{\mathrm{ab}} \pm 0.95$ & $34.84^{\mathrm{b}} \pm 0.77$ & $33.19^{\mathrm{ab}} \pm 1.25$ & $33.35^{\mathrm{ab}} \pm 0.51$ & $31.73^{\mathrm{a}} \pm 0.58$ \\
$\mathrm{DMD}, \%$ & $24.61^{\mathrm{a}} \pm 3.41$ & $24.66^{\mathrm{a}} \pm 0.45$ & $25.02^{\mathrm{a}} \pm 0.84$ & $26.66^{\mathrm{a}} \pm 0.80$ & $33.78 \mathrm{~b} \pm 1.39$ \\
$\mathrm{CP} / 100 \mathrm{~g}$ DM & $7.61^{\mathrm{a}} 0.14$ & $6.18^{\mathrm{b}} \pm 0.19$ & $7.57^{\mathrm{a}} \pm 0.34$ & $6.63^{\mathrm{ab}} \pm 0.91$ & $7.37^{\mathrm{ab}} \pm 0.51$ \\
NDF $/ 100 \mathrm{~g}$ DM & $81.06^{\mathrm{a}} \pm 4.55$ & $75.90^{\mathrm{ab}} \pm 0.30$ & $72.17^{\mathrm{b}} \pm 0.81$ & $72.43^{\mathrm{b}} \pm 1.12$ & $69.39^{\mathrm{b}} \pm 3.05$ \\
ADF $/ 100 \mathrm{~g} \mathrm{DM}$ & $46.99^{\mathrm{a}} \pm 0.58$ & $45.07^{\mathrm{ab}} \pm 1.33$ & $43.99^{\mathrm{b}} \pm 0.72$ & $42.80^{\mathrm{b}} \pm 0.60$ & $43.19^{\mathrm{b}} \pm 1.04$ \\
ADL $/ 100 \mathrm{~g}$ DM & $7.43^{\mathrm{a}} \pm 0.40$ & $7.59^{\mathrm{a}} \pm 0.26$ & $9.29^{\mathrm{ab}} \pm 2.93$ & $13.12^{\mathrm{bc}} \pm 1.14$ & $15.38^{\mathrm{c}} \pm 2.59$ \\
EE /100g DM & $2.06^{\mathrm{a}} \pm 0.24$ & $2.02^{\mathrm{a}} \pm 0.01$ & $2.32^{\mathrm{a}} \pm 0.18$ & $2.03^{\mathrm{a}} \pm 0.12$ & $1.39^{\mathrm{b}} \pm 0.38$ \\
Ash /100g DM & $11.65^{\mathrm{a}} \pm 1.07$ & $12.49^{\mathrm{ab}} \pm 0.43$ & $15.63^{\mathrm{ab}} \pm 1.67$ & $16.08^{\mathrm{bc}} \pm 1.49$ & $19.92^{\mathrm{c}} \pm 2.22$
\end{tabular}

DM: dry matter, CP: crude protein, NDF: neutral detergent fibre, ADF: acid detergent fibre, ADL: acid detergent lignin,

EE: extract ether, DMD: in vitro dry matter digestibility; $\mathrm{NaOH}$ : sodium hydroxide

${ }_{\mathrm{a}, \mathrm{b}, \mathrm{c}}$ Within a row, means with a common superscript were not different with probability $P=0.05$

Crude protein showed a small decrease when the $\mathrm{NaOH}$ treatment was applied. This observed decrease was consistent with previous studies and was a disadvantage of this treatment when compared with others, such as treatment with ammonia or urea, which are sources of non-protein nitrogen (Madrid et al., 1998). The decrease in NDF was most evident with the $8 \%$ concentration of $\mathrm{NaOH}$. Similar results were reported by Pereira Filho et al. (2003), who indicated that increasing $\mathrm{NaOH}$ from $2 \%$ to $8 \%$ in black Jurema hay decreased its NDF content. The main effect of $\mathrm{NaOH}$ on cell wall components is the alkaline hydrolysis of covalent ester-like bonds between lignin and structural carbohydrates (Tarkov \& Feist, 1969). Thus, hemicellulose becomes soluble with a consequent decrease in the NDF content (Wannapat et al., 1985; Chaudhry, 2000). This facilitates fibre digestion by rumen microbes. In general, there was no discernible trend in ADF content resulting from the $\mathrm{NaOH}$ treatments. Many other studies have shown that the use of $\mathrm{NaOH}$ to treat fibrous foods does not alter ADF (Manzano et al., 2000; Chaudhry, 1997; Sundstøl \& Coxworth, 1984). In the work of Nolte et al. (1987), a decrease in ADF was obtained for wheat straw treated with an alkaline solution. A significant increase $(P<0.05)$ of ADL was observed with the $6 \%$ and $8 \% \mathrm{NaOH}$ treatments compared with the control. Lignin content is not normally altered by chemical treatment, but this treatment led to increases in the rate of digestion of cellulose and hemicellulose by breaking links between these fractions (Feist et al., 1970; Klopfenstein, 1980). The effect on $\mathrm{EE}$ of $\mathrm{NaOH}$ treatment of $A$. donax was not easily explained as there were no previously published studies on which to rely. The mineral residue from $\mathrm{NaOH}$ resulted in the expected increase in ash content with the increasing levels of $\mathrm{NaOH}$. This increase was seen earlier by Moss et al. (1993).

Unlike in the present study, Pereira Filho et al. (2003), observed a significant increase $(P<0.05)$ in the DMD of black Jurema hay as the level of $\mathrm{NaOH}$ with which it was treated increased. Chaudhry (1997) pointed out that normally DMD of forages treated with an alkaline solution had a positive linear relationship when increasing levels of $\mathrm{NaOH}$ up to $8 \%$. NaOH has been used frequently with other alkaline compounds and physical treatment because it was believed to be one of the most efficient chemical products for delignification of cell wall compounds in plant cells. The increase in the DMD of forage treated with $\mathrm{NaOH}$ 
occurred because of the greater exposure of the cell wall components, increasing the susceptibility of structural carbohydrates to digestibility (Chaudhry, 1998).

Cumulative gas production as affected by treatment of $A$. donax forage with various levels of $\mathrm{NaOH}$ is shown in Table 2 and Figure 1. The in vitro GP technique simulates the rumen fermentation process and has been used frequently to evaluate the potential of food to produce gas. When the authors observed the lag time, they could see that $A$. donax supplemented with $2 \% \mathrm{NaOH}$ began to ferment after 1.5 hours, which was before any of the other samples. The treatment with $\mathrm{NaOH}$ triggered a lower gas production, especially in the treatment with $8 \%$, which could be a positive aspect in mitigating enteric gas production and consequently combating climate change.

Table 2 Effect of sodium hydroxide treatment on Arundo donax on cumulative gas production $\left(\mathrm{ml} 200 \mathrm{mg}^{-}\right.$ $\left.{ }^{1} \mathrm{DM}\right)$ and gas kinetics

\begin{tabular}{cccccc}
\hline \multirow{2}{*}{ Incubation time, hours } & \multicolumn{5}{c}{ Treatment } \\
\cline { 2 - 6 } & Control & $2 \% \mathrm{NaOH}$ & $4 \% \mathrm{NaOH}$ & $6 \% \mathrm{NaOH}$ & $8 \% \mathrm{NaOH}$ \\
\hline & 1.18 & 1.45 & 1.53 & 1.28 & 0.94 \\
8 & 3.54 & 3.64 & 4.08 & 3.41 & 2.84 \\
12 & 5.74 & 5.66 & 6.40 & 5.39 & 4.72 \\
24 & 11.40 & 10.87 & 12.20 & 10.49 & 9.49 \\
48 & 19.54 & 18.29 & 19.86 & 17.82 & 16.52 \\
72 & 24.73 & 24.20 & 24.22 & 22.49 & 21.18 \\
96 & 28.04 & 26.69 & 26.69 & 25.74 & 24.26 \\
\hline Kinetic parameter estimates & & & & -1.01 & -1.15 \\
\hline a & -1.36 & 0.91 & -1.28 & 31.70 & 31.43 \\
b & 35.21 & 31.84 & 31.24 & 0.0188 & 2.20 \\
c & 0.0188 & 0.0192 & 0.0235 & 1.70 & \\
Lag time & 2.10 & 1.50 & 1.80 & &
\end{tabular}

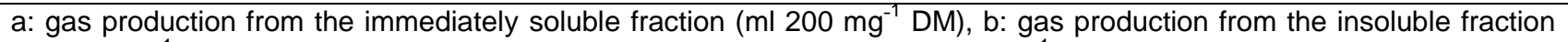
$\left(\mathrm{ml} 200 \mathrm{mg}^{-1} \mathrm{DM}\right), \mathrm{c}$ : gas production rate constant for the insoluble fraction $\left(\mathrm{ml} \mathrm{h}^{-1}\right) ; \mathrm{NaOH}$ : sodium hydroxide 


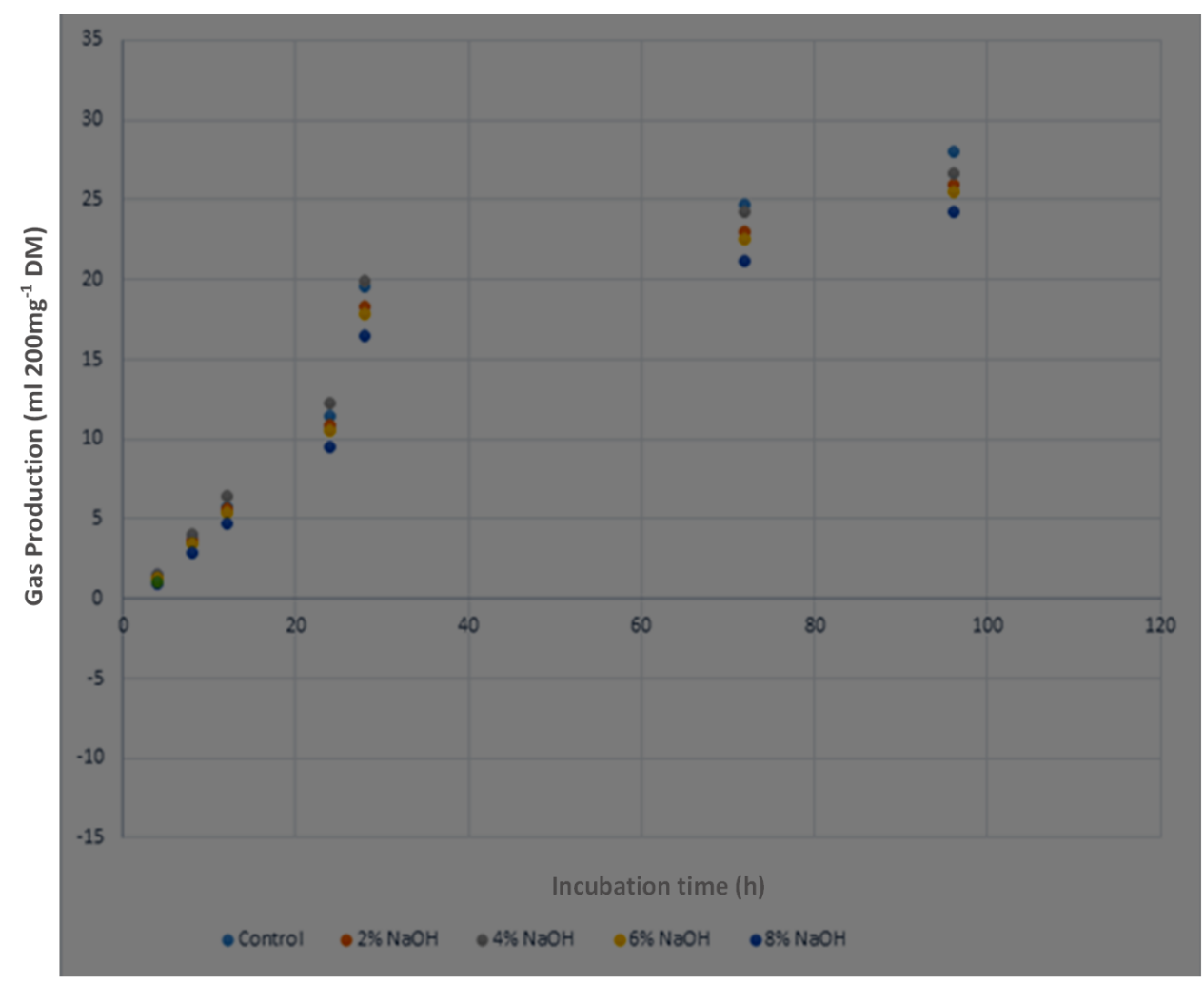

Figure 1 Pattern of in vitro gas production (fitted with exponential model) on incubation of Arundo donax treated with sodium hydroxide $(\mathrm{NaOH})$ in buffered rumen fluid

\section{Conclusions}

Treatment of $A$. donax forage with $8 \% \mathrm{NaOH}$ optimized its value because it decreased NDF and total gas production compared to the other treatments. Thus, treatment with $\mathrm{NaOH}$ improves $A$. donax as a feed for animals.

\section{Acknowledgments}

This work was funded by INV2MAC Project (Potencial aprovechamiento de biomasa generada a partir de especies vegetales invasoras de la Macaronesia para uso industrial, MAC2/4.6a/229), and approved in the first call of the territorial cooperation programme MAC towards FEDER funds and the Regional Directorate of Science and Technology of the Azorean Regional Secretariat for the Sea, Science and Technology. The authors also express their appreciation to IITAA (Institute of Agrarian Investigation) for support of this research from FCT project ref: UIDB/00153/2020 and permission to use their research facilities.

\section{Authors' Contributions}

SMPT collected the data, performed the subsequent laboratory analysis and prepared the manuscript. CSAMMD and SMPT collaborated in the experimental design. CFMV and JSM conducted the statistical analysis. AESB supervised the work and reviewed the manuscript.

\section{Conflict of Interest Declaration}

None of the authors has any conflict of interest.

\section{References}

Alexander, R.H. \& McGowan, M., 1966. The routine determination of in vitro digestibility of organic matter in forages. An investigation of the problems associated with continuous large-scale operation. J. Brit. Grassl. Soc. 21, 140-147. https://doi.org/10.1111/j.1365-2494.1966.tb00462.x

Association of Official Analytical Chemists (AOAC), 1995. Official methods of analysis. 16th edition. AOAC, Virginia, USA. ISBN: 09355845449780935584547

Bertipaglia, L.M.A., Luca, S., Melo, G.M.P. 2005. Avaliação de fontes de urease na amonização de fenos de Brachiaria brizantha com dois teores de umidade. Revista Brasileira de Zootecnia 34(2), 378-386. http://dx.doi.org/10.1590/S1516-35982005000200004

Borba, A.E.S., 2006. Alimentos fibrosos de baixa qualidade. Universidade dos Açores, Departamento de ciências Agrárias, Angra do Heroísmo. P. 18. 
Borba, A.E.S., 2007. Produção animal tradicional da Ilha de S. Jorge. Agroforum 19(15), 29-34. ISSN: 0872-2617

Borba, J., 2015. Valorização nutritiva da fibra para a alimentação animal: Tratamento com ureia. Dissertação de Mestrado em Engenharia Zootécnica. Universidade dos Açores, Departamento de Ciências Agrárias. Angra do Heroísmo, Açores Portugal. http://hdl.handle.net/10400.3/3508

Borba, J.P.R., Maduro Dias, C.S.A.M., Rosa, H.J.D., Vouzela, C.F.M., Rego, O.A. \& Borba, A.E.S., 2015. Nutritional valorization of ginger lily forage (Hedychium gardnerianum Sheppard ex Ker-Gawl) for animal feeding: Treatment with urea. African J. Agric. Res. 10, 4606-4615. https://doi.org/10.5897/AJAR2015.10075

Chaudhry, A.S., 1997. Washing and filtration of wheat straw treated with sodium hydroxide alone or with hydrogen peroxide to modify cell wall composition and in vitro digestibility. Australian Journal of Experimental Agriculture 37, 617-621. DOI: 10.1071/EA97011

Chaudhry, A.S., 1998. Nutrient composition, digestion and rumen fermentation in sheep of wheat straw treated with calcium oxide, sodium hydroxide and alkaline hydrogen peroxide. Animal Feed Science and Technology 74, 315328. https://doi.org/10.1016/S0377-8401(98)00178-3

Chaudhry, A.S., 2000. Rumen degradation in sacco in sheep of wheat straw treated with calcium oxide, sodium hydroxide and sodium hydroxide plus hydrogen peroxide. Animal Feed Science and Technology 83, 313-323. https://doi.org/10.1016/S0377-8401(99)00134-0

Chen, X.B., 1997. Neway Excel: A utility for processing data of feed degradability and in vitro gas production (version 5.0). Rowett Research Institute, UK.

Feist, W.C., Baker, A.J. \& Tarkow, H., 1970. Alkali requirements for improving digestibility of hardwoods by rumen microorganisms. J. Animal Science 30, 832-835. https://doi.org/10.2527/jas1970.305832x

Goering, H.K. \& Van Soest, P.J., 1970. Forage fiber analyses. Agricultural Handbook 379, Washington DC, USA.

Klopfenstein, T., 1980. Increasing the nutritive value of crop residues by chemical treatments. In: J.T. Huber (ed). Upgrading residues and products for animals. CRC Press. Boca Raton, FL. P. 40. ISBN: 9781351077453

Madrid, J., Hernández, F. \& Pulgar, M.A., 1998. Effects of citrus by-product supplementation on the intake and digestibility of urea + sodium hydroxide-treated barley straw in goats. Small Ruminant Research 28, 241-248. https://doi.org/10.1016/S0921-4488(97)00086-2

Manzano, R.P., Fukushima, R.S. \& Gomes, J.D.F., 2000. Digestibilidade do bagaço de cana-de-açúcar tratado com reagentes químicos e pressão de vapor. Revista Brasileira de Zootecnia 29(4), 1196-1204. https://doi.org/10.1590/S1516-35982000000400034

McDonald, I., 1981. A revised model for the estimation of protein degradability in the rumen. J. Agric. Sci. 96, $251-252$. https://doi.org/10.1017/S0021859600032081

Menke, K.H. \& Steingass, H., 1988. Estimation of the energetic feed value obtained from chemical analysis and in vitro gas production using rumen fluid. Anim. Res. Develop. 28, 7-55.

Menke, K. H., Raab, L., Salewski, A., Steingass, H., Fritz, D. \& Schneider, W. 1979. The estimation of the digestibility and metabolizable energy content of ruminant ISSN: 0021-8596/79/2828-2280

Moss, A.R., Givens, D.I. \& Furniss, S., 1993. A comparison of farm-scale methods of application of sodium hydroxide on the nutritive value of a winter wheat straw. Animal Feed Science and Technology 41, 199-212. https://doi.org/10.1016/0377-8401(93)90013-A

Nolte, M.E., Cline, J.H. \& Dehority, B.A., 1987. Treatment of wheat straw with alkaline solutions prepared from wood ashes to improve fiber utilization by ruminants. Journal Animal Science 64,1516-1528. DOI: 10.2527/JAS1987.643669X

Ørskov, E.R. \& McDonald, P., 1979. The estimation of protein degradability in the rumen from incubation measurements weighted according to rate of passage. J. Agric. Sci. 92, 499-503. https://doi.org/10.1017/S0021859600063048

Pereira Filho, J.M., Vieira, E.L., Silva, A.M.A., Cezar, M.F. \& Amorim, F.U., 2003. Effect of sodium hydroxide treatment on fiber fraction, digestibility and tannin of Jurema-Preta hay (Mimosa tenuiflora Wild). Rural Bras. Zootec. 32, 7076. http://dx.doi.org/10.1590/S1516-35982003000100009

Pezo, D., 1991. La calidad nutritiva de los forrajes. Produccion y utilizacion de forrajes en el tropico. Compendio. Serie Materiales de Ensenanza número 15.

Pires, A.J.V., Reis, R.A. \& Carvalho, G.G.P., 2006. Bagaço de cana tratado com hidróxido de sódio. Revista Brasileira de Zootecnia 35 (3), 953-957. https://doi.org/10.1590/S1516-35982006000400003

Rocha, B., Maduro Dias, C.S.A.M., Vouzela, C.F.M., Rosa, H.J.D., Madruga, J.S. \& Borba, A.E.S., 2019. Nutritional valorization of Arundo donax by treatment with urea. 70th annual meeting of the European Federation of Animal Science (EAAP). https://academicjournals.org/journal/AJAR/article-abstract/8FDB66F65234

Rocha, S., 2016. Valorização nutritiva da fibra de conteira (Hedychium gardnerianum Sheppard ex Ker-Gawl) na alimentação animal. Dissertação de Mestrado em Engenharia Zootécnica. Universidade dos Açores, Departamento de Ciências Agrárias. Angra do Heroísmo, Açores, Portugal. http://hdl.handle.net/10400.3/4327

SundstøI, F. \& Coxworth, E.M., 1984. Ammonia treatment. In: F. SundstøI \& E. Owen (eds). Straw and other fibrous byproducts as feed. Developments in Animal Veterinary Sciences 14, 196-247. ISBN 0-444-42302-8

Tarkov, H. \& Feist, W.C., 1969. A mechanism for improving the digestibility of lignocellulosic materials with dilute alkali and liquid ammonia. Advances in Chemistry Series 95, 197-218. DOI: 10.1021/ba-1969-0095.ch012

Tilley, J.M.A. \& Terry, R.A., 1963. A two-stage technique for the in vitro digestion of forage crops. Grass and Forage Science 18, 104-111. https://doi.org/10.1111/j.1365-2494.1963.tb00335.x 
Wanapat, M., SundstøI, F. \& Garmo, T.H., 1985. A comparison of alkali treatment methods to improve the nutritive value of straw. I. Digestibility and metabolizability. Animal Feed Science \& Technol. 12, 295-309. https://doi.org/10.1016/0377-8401(85)90006-9 